Article

\title{
The Influence of the Application Technique and Amount of Liquid Starter Fertilizer on Corn Yield
}

\author{
Milan Drazic ${ }^{1}$, Kosta Gligorevic ${ }^{1}$, Milos Pajic ${ }^{1}$, Ivan Zlatanovic ${ }^{1}{ }^{\mathbb{B}}$, Velibor Spalevic ${ }^{2, *}$, \\ Paul Sestras ${ }^{3}$ (D) Goran Skataric ${ }^{4,5}$ and Branislav Dudic $5,6, * \mathbb{D}$ \\ 1 Faculty of Agriculture, University of Belgrade, Nemanjina 6, 11080 Belgrade-Zemun, Serbia; \\ mdrazic@agrif.bg.ac.rs (M.D.); koleg@agrif.bg.ac.rs (K.G.); paja@agrif.bg.ac.rs (M.P.); \\ ivan@agrif.bg.ac.rs (I.Z.) \\ 2 Geography Department of the Faculty of Philosophy, University of Montenegro, Danila Bojovica bb, \\ 81400 Niksic, Montenegro \\ 3 Department of Land Measurements and Cadaster, Faculty of Civil Engineering, Technical University of \\ Cluj-Napoca, 400114 Cluj-Napoca, Romania; psestras@mail.utcluj.ro \\ 4 National Parks of Montenegro, 81000 Podgorica, Montenegro; goran.skataric@yahoo.com \\ 5 Faculty of Economics and Engineering Management, University Business Academy, 21102 Novi Sad, Serbia \\ 6 Faculty of Management, Comenius University in Bratislava, 81102 Bratislava, Slovakia \\ * Correspondence: velibor.spalevic@ucg.ac.me (V.S.); branislav.dudic@fm.uniba.sk (B.D.); \\ Tel.: +382-67-201-222 (V.S.); +421-250-117-403 (B.D.)
}

Received: 5 July 2020; Accepted: 5 August 2020; Published: 10 August 2020

check for updates

\begin{abstract}
The aim of this research was to study the impact of application technique and rate of liquid starter fertilizer applied with a novel device on the production of corn. Starter fertilizer was applied in the root system range of freshly germinated plants in the 'belt' and 'point' forms at different quantities $\left(35,50,70\right.$, and $\left.100 \mathrm{~L} \mathrm{ha}^{-1}\right)$, which led to intensive plant growth in the initial stages of development. This adapted system was used for sowing and for application of the liquid starter fertilizer at the same time. The field trial was set up at two sites (two different land types), in the conditions of the natural water regime of the soil during the three vegetation seasons in the period 2016-2018. For this purpose, a prototype of the electronic device EUKU-01 was designed. The starter fertilizer was applied at $5 \mathrm{~cm}$ laterally from the row where the sowing was performed and $5 \mathrm{~cm}$ below the depth at which the corn seeds were sown. Data were statistically analyzed by two-factor analysis of variance, where the influence of mineral fertilizer treatment and the influence of liquid starter fertilizer treatment were observed as factors. The results showed that the optimal choice of the technique of liquid starter fertilizer application can result in fertilizer savings by $30 \%$ without reducing yield.
\end{abstract}

Keywords: starter fertilizer; application technique; corn; yield; corn planter; an electronic device

\section{Introduction}

Over the last two decades of the 20th century and the first decade of the 21st century, the average corn yield in the world has increased by 70\%. This increase has been the result of constant progress in the breeding and development of increasingly fertile hybrids, application of different types and forms of fertilizers, but also the development of agricultural machines that are used to perform the necessary technological operations [1-3].

Sowing of corn, as a technological phase of production, is one of the most important elements of production technology because it directly affects the achieved yield [4,5]. Shortcomings and irregularities made during sowing can hardly be corrected by other cultural measures, which directly leads to a reduction in yield [6]. 
The choice of certain types of fertilizer, and especially the methods and techniques of their application, is one of the specific cultural practices that can significantly affect the increase in yield. Fertilizers must be used in a timely way and at sufficient quantities [7-11]. One of the directions for increasing the obtained yields is the introduction of the application of starter fertilizers in the technology of corn production [12-15]. Starter fertilizer is defined as "the insertion of a small amount of nutrients near the place where the seeds will be placed during sowing" [16,17]. The basic fertilizer has the important task of providing the necessary and easily available nutrients (primarily phosphorus) to newly germinated seeds that are very sensitive to its lack or inaccessibility [18]. Over the phenophase of germination and emergence of corn, the nutrients contained in the starter fertilizer have a favorable effect on the rooting, growth and development of the root system of the plant [19-21]. Phosphorus (P) as a nutrient is crucial in the energy processes of the plant, and in synergy with zinc (Zn) directly affects the strong growth and development of roots [20,21].

The root system with a larger mass, volume and number of rootlets develops better in terms of the depth and width of the soil profile and uses the available reserves of nutrients and water in the soil more efficiently. A well-nourished and developed young plant is more tolerant of unfavorable climatic conditions as well as to pathogen attacks [22,23]. Faster, intensive and efficient growth of plants in the initial stages lead to uniform growth of corn plants throughout the field, less weed growth, as well as better moisture storage in the soil [23].

The application of starter fertilizers can be done in different ways depending on the type and chemical composition. When the starter fertilizer is applied together with the seed in the same furrow, there is a possibility of damaging the seed by the fertilizer, which can lead to a decrease in the number of plants and the total yield of corn [24]. Numerous studies show that the most favorable way is the application of starter fertilizer laterally from the row in which the sowing was done and below the depth at which the seed is placed [25-28]. If the starter fertilizer is applied in this way, it is easily accessible to the root of young newly germinated plants and the risk of seed damage is reduced [29]. The fertilizer band must be placed close enough to the seedling to provide nutrients but far enough away to avoid salt or ammonia injury. The most common placement is $5 \mathrm{~cm}$ below and $5 \mathrm{~cm}$ to the side of the seed row, although distances vary from 3 to $8 \mathrm{~cm}$ [29]. Technology of corn production implies the seeding in rows with the distance between the seeds of $15-22 \mathrm{~cm}[4,6]$.

The majority of available research usually deals with the starter fertilizer application in 'belt' form at specific distance from the seed. In that form of application, the starter fertilizer was applied close to the plant, as well as away from the plant, in a zone that newly developed root system of corn can be difficult to reach. The novelty of this study is to apply the starter fertilizer only in a zone reachable by the root system. Therefore, the starter fertilizer must be entered intermittently, i.e., 'point' forms. The assumption was made that this form of the application of the starter fertilizer will have unchanging impact on plant growth with a reduced amount of fertilizer applied at the same time. The current research was aimed at studying the impact of application technique and rate of liquid starter fertilizer applied with a novel applicator on the production of corn.

\section{Materials and Methods}

\subsection{Agro-Climatic Conditions}

The field trial was set up at two sites. Site 1 -the village of Banja $\left(44^{\circ} 18^{\prime} 31.3^{\prime \prime} \mathrm{N}, 20^{\circ} 38^{\prime} 25^{\prime \prime} \mathrm{E}\right)$, Sumadija district (Republic of Serbia), land type-Smonitza $\left(44^{\circ} 18^{\prime} 31.3^{\prime \prime} \mathrm{N}, 20^{\circ} 38^{\prime} 25^{\prime \prime}\right.$ E). Site 2-the village of Ratari $\left(44^{\circ} 38^{\prime} 21.3^{\prime \prime} \mathrm{N}, 20^{\circ} 06^{\prime} 00.6^{\prime \prime} \mathrm{E}\right)$, Belgrade district (Republic of Serbia), land type-Hydromorphous Black Soil $\left(44^{\circ} 38^{\prime} 21.3^{\prime \prime} \mathrm{N}, 20^{\circ} 06^{\prime} 00.6^{\prime \prime}\right.$ E) [30,31]. At the aforementioned sites, the research was performed in the conditions of the natural water regime of the soil during the three vegetation seasons in the period 2016-2018. 
The trials were set up on soil types mentioned above. Soil samples were taken at depths of 0-30 cm and 30-60 cm before basic tillage for each year of study. Methods for chemical analysis of soil are used [32-41] and the results are shown in Table 1.

Table 1. Basic chemical properties of soil at sites 1 and 2 .

\begin{tabular}{|c|c|c|c|c|c|c|c|c|c|c|c|c|}
\hline \multirow{2}{*}{ Year } & \multirow{2}{*}{ Site } & \multirow{2}{*}{$\begin{array}{c}\text { Depth } \\
\text { (cm) }\end{array}$} & \multicolumn{2}{|c|}{$\mathrm{pH}$} & Humus & Total N & $\mathrm{CaCO}_{3}$ & $\mathrm{Ca}$ & $\mathrm{P}_{2} \mathrm{O}_{5}$ & $\mathbf{P}$ & $\mathrm{K}_{2} \mathrm{O}$ & K \\
\hline & & & $\mathrm{H}_{2} \mathrm{O}$ & $1 \mathrm{M} \mathrm{KCL}$ & \multicolumn{4}{|c|}{$(\%)$} & \multicolumn{4}{|c|}{$\mathrm{mg} / 100 \mathrm{~g}$} \\
\hline \multirow{4}{*}{2016} & \multirow{2}{*}{1} & $0-30$ & 6.79 & 6.08 & 2.75 & 0.31 & 0 & 0 & 15.9 & 6.94 & 25.7 & 21.42 \\
\hline & & $30-60$ & 6.51 & 5.95 & 2.69 & 0.26 & 0 & 0 & 12.3 & 5.37 & 24.9 & 20.75 \\
\hline & \multirow{2}{*}{2} & $0-30$ & 6.72 & 6.42 & 3.26 & 3.46 & 0 & 0 & 17.9 & 7.81 & 22.1 & 18.42 \\
\hline & & $30-60$ & 7.10 & 6.69 & 2.77 & 2.93 & 0.5 & 0.2 & 12.1 & 5.28 & 24.9 & 20.75 \\
\hline \multirow{4}{*}{2017} & \multirow{2}{*}{1} & $0-30$ & 6.54 & 6.14 & 2.29 & 0.22 & 0 & 0 & 16.9 & 7.38 & 20.9 & 17.42 \\
\hline & & $30-60$ & 6.32 & 5.97 & 2.35 & 0.26 & 0 & 0 & 14.3 & 6.24 & 19.1 & 15.92 \\
\hline & \multirow{2}{*}{2} & $0-30$ & 6.93 & 6.31 & 3.29 & 2.71 & 0 & 0 & 18.6 & 8.12 & 24.4 & 20.33 \\
\hline & & $30-60$ & 7.43 & 6.50 & 2.71 & 2.8 & 0.1 & 0.04 & 15.0 & 6.55 & 20.5 & 17.08 \\
\hline \multirow{4}{*}{2018} & \multirow{2}{*}{1} & $0-30$ & 7.21 & 6.31 & 2.47 & 0.28 & 0 & 0 & 17.3 & 7.55 & 19.9 & 16.58 \\
\hline & & $30-60$ & 6.77 & 6.35 & 2.46 & 1.98 & 0 & 0 & 15.1 & 6.59 & 21.3 & 17.75 \\
\hline & \multirow[b]{2}{*}{2} & $0-30$ & 6.80 & 6.79 & 2.82 & 3.25 & 1.2 & 0.48 & 16.6 & 7.25 & 22.7 & 18.92 \\
\hline & & $30-60$ & 7.11 & 6.85 & 2.60 & 2.72 & 1.6 & 0.64 & 14.9 & 6.51 & 18.1 & 15.08 \\
\hline
\end{tabular}

During the research in the experimental variants (Figure 1), conventional mineral fertilizers NPK (N:P:K = 15:15:15) and KAN with 27\% N (13.5\% $\mathrm{NH}_{4}-\mathrm{N}$ and $\left.13.5 \% \mathrm{NO}_{3}-\mathrm{N}\right)$ were applied in the following amounts: $0+0 \mathrm{~kg} \mathrm{ha}^{-1} ; 150+100 \mathrm{~kg} \mathrm{ha}^{-1}$ and $300+200 \mathrm{~kg} \mathrm{ha}^{-1}$. Based on available research $[30,31,42,43]$, the amount of $100 \mathrm{~L} \mathrm{ha}^{-1}$ of starting fertilizer was taken as the optimal value. Also, some of the research in the field [38] indicates that, in case of 'belt' form application, corn plants effectively adopt only $70 \%$ of the total amount of applied starter fertilizer. Therefore, in this research it was assumed that the same effect will be achieved if 'belt' form amounts were replaced with $30 \%$ less than the amounts in 'point' form. In addition to the above, liquid starter fertilizer Starter-A (N:P:K 10:40:10, inorganic, liquid) was applied in the amounts of: $100 \mathrm{~L} \mathrm{ha}^{-1}$ 'belt' form (i.e., 30\% less is $70 \mathrm{~L} \mathrm{ha}^{-1}$ in 'point' form) and $50 \mathrm{~L} \mathrm{ha}^{-1}$ 'belt' form (i.e., $30 \%$ less is $35 \mathrm{~L} \mathrm{ha}^{-1}$ in 'point' form). The chemical composition of the applied liquid starter fertilizer is shown in Table 2.

Table 2. The chemical composition of the applied Starter-A fertilizer.

\begin{tabular}{|c|c|}
\hline Nutrients & Content \\
\hline Nitrogen $(\mathrm{N})$ & $10 \% /-1.1 \%\left(8 \%\right.$ of $\mathrm{NH}_{4}-\mathrm{N}, 2 \%$ of $\left.\mathrm{NO}_{3}-\mathrm{N}\right)$ \\
\hline Phosphorus (as $\left.\mathrm{P}_{2} \mathrm{O}_{5}\right)$ & $40 \% /-1.1 \%$ (water-soluble) \\
\hline Potassium $\left(\right.$ as $\left.\mathrm{K}_{2} \mathrm{O}\right)$ & $10 \% /-1.1 \%$ (water-soluble) \\
\hline Boron (B) & $0.02 \% /-0.004 \%$ \\
\hline Copper $(\mathrm{Cu})$ EDTA & $0.015 \% /-0.003 \%$ \\
\hline Iron (Fe) DTPA & $0.04 \% /-0.008 \%$ \\
\hline Manganese (Mn) EDTA & $0.04 \% /-0.008 \%$ \\
\hline Molybdenum (Mo) & $0.008 \% /-0.0016 \%$ \\
\hline Zink (Zn) EDTA & $0.015 \% /-0.004 \%$ \\
\hline Heavy Metals & Maximum Content in $\mathrm{mg} / \mathrm{kg}$ by Dry Weight of Plant Nutrition Products \\
\hline Lead $(\mathrm{Pb})$ & 100 \\
\hline Cadmium $(\mathrm{Cd})$ & $75 \mathrm{mg} / \mathrm{kg} \mathrm{P}_{2} \mathrm{O}_{5}$ \\
\hline Chrome(Cr) & 500 \\
\hline Nickel (Ni) & 100 \\
\hline Mercury (Hg) & 1 \\
\hline
\end{tabular}




\subsection{Trial Design and Applied Corn Production Technology}

Field trials were carried out using the split-plot method, from experimental plots E1 to E15 (see Figure 1). The size of all plots on which different treatments were applied was $11.2 \times 90 \mathrm{~m}$. Each of the plots, from E1 to E15 contains 16 rows.

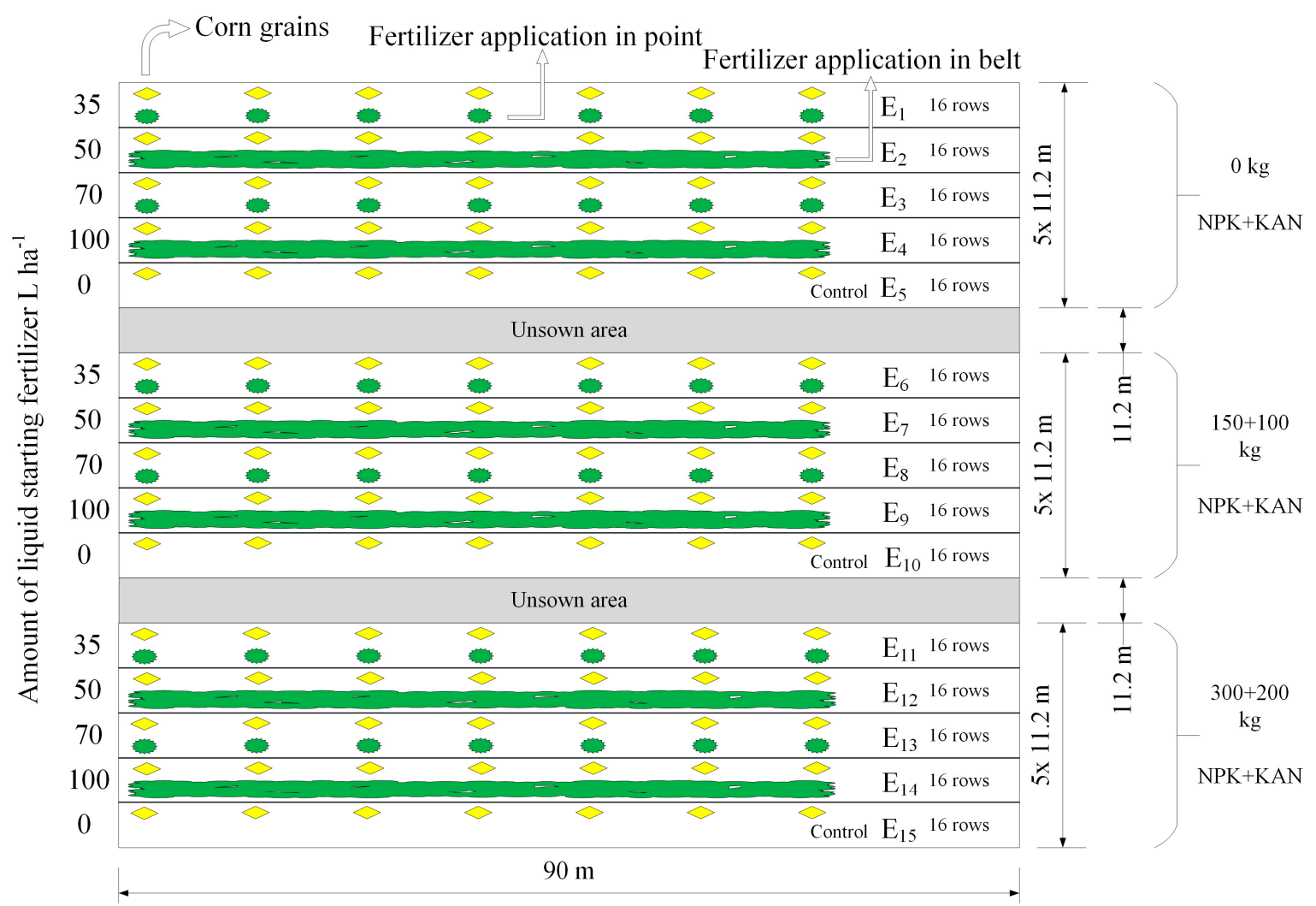

Figure 1. A scheme of the established trial.

In all three years of research, winter wheat was a preceding crop to corn at the aforementioned sites. After the wheat harvest, the plant remains were removed and the stubble was plowed down to a depth of $10-15 \mathrm{~cm}$. In the fall, before plowing $(30 \mathrm{~cm}$ depth), mineral fertilizers were spread in different amounts. Mineral fertilizer was not applied to the plots from E1 to E5. Moreover, $150 \mathrm{~kg} \mathrm{ha}^{-1}$ was applied to the plots from E5 to E10, and $300 \mathrm{~kg} \mathrm{ha}^{-1}$ of NPK fertilizers were applied to the plots E10 to E15. In the spring, immediately before the preparation of the land for sowing, the mineral fertilizer KAN was applied in the amount of $100 \mathrm{~kg} \mathrm{ha}^{-1}$ to plots E5 to E10 and $200 \mathrm{~kg} \mathrm{ha}^{-1}$ to plots E10 to E15. After the application of mineral fertilizers, pre-sowing preparation was performed on two swaths using a corn planter and a spike harrow.

Sowing of medium-early corn hybrid ZP 427 (Maize research Institute "Zemun Polje", Belgrade, Republic of Serbia) was performed using an IMT634.454 (Industry of Machinery and Tractors, Belgrade, Republic of Serbia) corn planter with a row spacing of $70 \mathrm{~cm}$ and $65,000 \mathrm{ha}^{-1}$ plants. Sowing was done in the second decade of April for all three years of research using the IMT-634.454 corn planter on all plots from E1 to E15. No starter fertilizer was applied to plots E5, E10 and E15 (Control plot). The adapted corn planter was used on the other plots where the liquid starter fertilizer (Starter-A) was applied. Adapting the corn planter and installing the prototype of the electronic device EUKU-01 enabled automatically sub-surface applying of the set doses of liquid starter fertilizer at the same time when sowing corn.

Within the conducted research, using the prototype of the electronic device EUKU-01, two technical systems of automatic subsurface application of liquid starter fertilizer were applied. The fertilizer was 
applied to the 'point' and 'belt' forms (Figure 2). The application of liquid starter fertilizer in the belt form meant the application of fertilizer in the form of a continuous belt $25 \mathrm{~mm}$ wide next to the row in which the corn seeds were sown. The second method of application meant that the liquid starter fertilizer was applied to the point form (diameter $r=25 \mathrm{~mm}$ ) individually next to each sown seed. In both cases, the liquid starter fertilizer was applied laterally from the row in which the corn seed was sown, at a distance of $5 \mathrm{~cm}$, as well as below the depth of $5 \mathrm{~cm}$ at which the corn seed was sown. Two-by-two placement of starter fertilizer was used by Gatiboni [44].
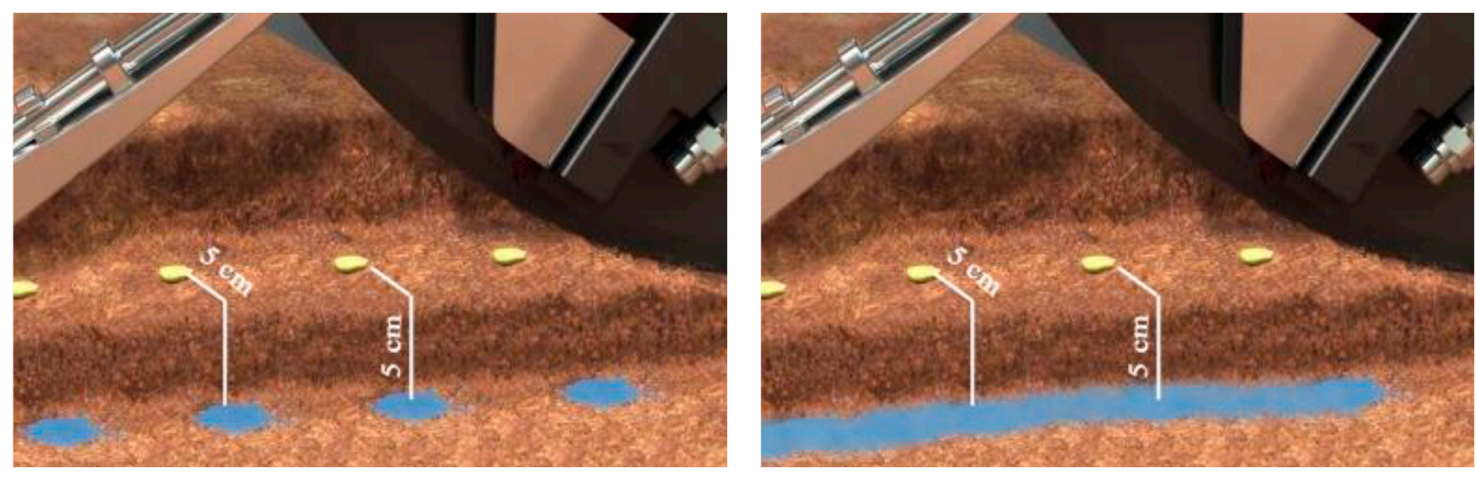

Figure 2. Applied methods of applying liquid starter fertilizer to the point and the belt.

For weed control, a combination of the herbicides Laudis $\left(2 \mathrm{~L} \mathrm{ha}^{-1}\right)$ and Callisto $\left(200 \mathrm{~g} \mathrm{ha}^{-1}\right)$ was applied to all plots (E1 to E15) in all three years of research at both sites. A tractor in aggregate with an AGS 440 (Agromehanika, Kranj, Republic of Slovenia) sprayer was used for the application of herbicides. Interrow cultivation was performed using an IMT-626.40 (Industry of Machinery and Tractors, Belgrade, Republic of Serbia) interrow cultivator.

The yield of pure corn grain was obtained by separately harvesting each variant and reducing it to $14 \%$ grain moisture. Harvesting was performed in the optimal time, with a universal grain harvester CLAAS LEXION 430 (CLASS Group, Harsewinkel, Germany), and before calculating the yield for each trial variant, the water content in the corn grain was determined by drying at $105^{\circ} \mathrm{C}$. Grain yield with the water content of $14 \%$ was calculated by the Equation (1):

$$
\mathrm{Q}=\mathrm{P} \times(100-\mathrm{U}) / 100-\mathrm{H}
$$

\subsection{The Working Principle of the Prototype of the Electronic Device EUKU-01}

Schematic and basic construction components of the prototype of the electronic device EUKU-01 (Ciga Factory, Aranđelovac, Republic of Serbia) is shown in Figure 3.

During sowing, the sowing apparatus of the corn planter performs individual sowing of corn seeds which after separating from the sowing plate fall into the open sowing furrow. Photoelectric sensors (position 2) placed under the sowing devices; at the moment of falling (movement of the grain from the sowing plate to the sowing furrow) generate signals which are sent to the electronic control unit (position 3) via an electrical conductor (position 5). After receiving the signal from the sensor of the sowing sections, the electronic control unit processes and generates the output signals which control the operation of the electric injectors (opening/closing) (position 1). With an electric pump (position 10), which is located in the tank (position 9), the liquid starter fertilizer is delivered under pressure to the electric injectors.

In the moment of time when it is necessary to apply liquid starter fertilizer, the electronic control unit sends a signal that opens the valve of the electric injector and in that way enables the application of fertilizer (Figure 4). By adjusting the operating parameters of the electronic control unit, it is possible to automatically apply the liquid starter fertilizer in different amounts $\left(\mathrm{L} \mathrm{ha}^{-1}\right)$ and by different application techniques. 


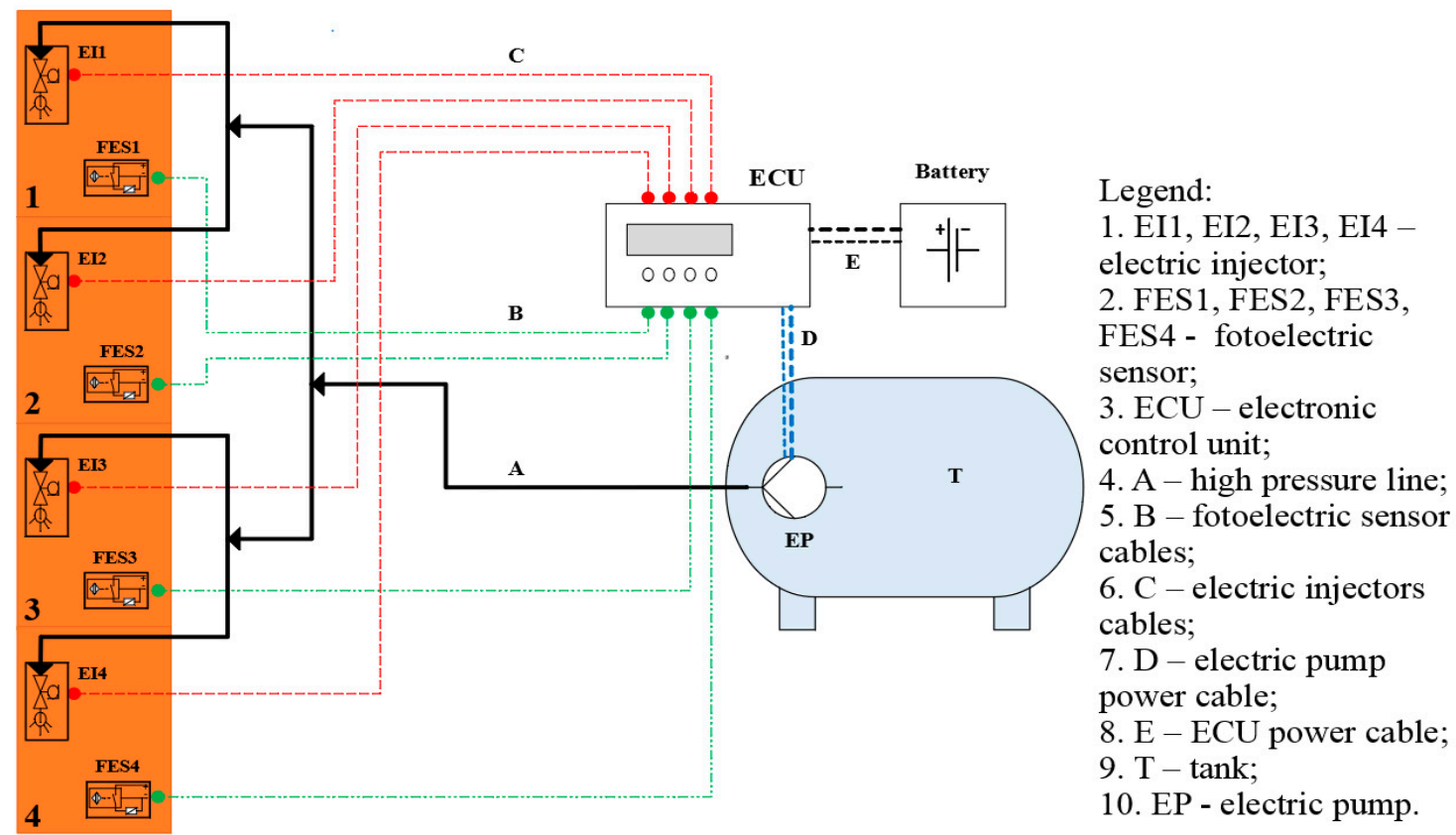

Figure 3. The electronic device EUKU-01 schematic (Source: Original).
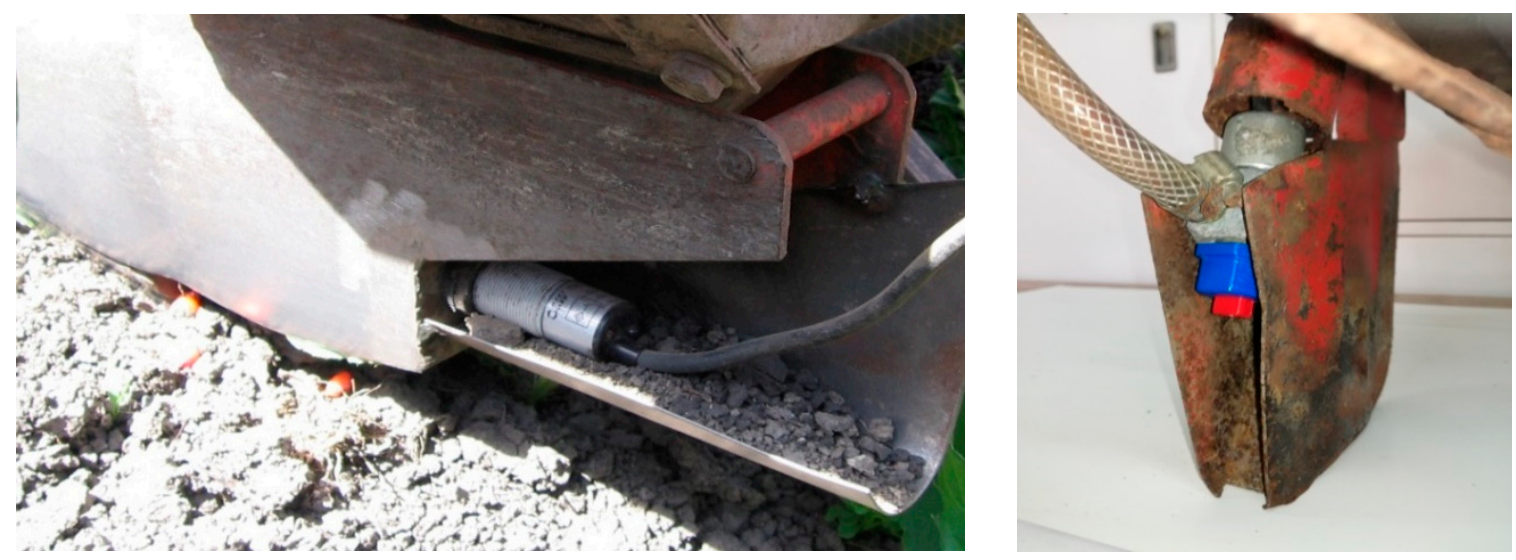

Figure 4. Photo electric sensor and the electric injector (Source: Original).

An electric injector with sprayers from the manufacturer 'Lechler' shown in Table 3 was used for the application of the starter fertilizer.

Table 3. Basic parameters of the starter fertilizer application technique.

\begin{tabular}{cccc}
\hline $\begin{array}{c}\text { Starter Fertilizer } \\
\text { Application Technique }\end{array}$ & Sprayer Designation & Working Pressure (bar) & $\begin{array}{c}\text { Starter Fertilizer } \\
\text { Amount (L ha } \mathbf{~}^{\mathbf{1}} \text { ) }\end{array}$ \\
\hline Application in belt & TR 80-02 & 3 & 100 \\
Application in point & ID-120-08 & 8 & 70 \\
Application in belt & TR 80-01 & 3 & 50 \\
Application in point & ID-120-04 & 8 & 35 \\
\hline
\end{tabular}

By applying different application techniques, the amount of starter fertilizer and the amount of mineral fertilizers on plots from E1 to E15, a total of 5 different treatments were obtained, as shown in Table 4. 
Table 4. Treatments, amounts and techniques of application of applied fertilizers.

\begin{tabular}{|c|c|c|c|c|}
\hline \multirow{2}{*}{$\begin{array}{c}\text { Liquid Starter } \\
\text { Fertilizer Treatments }\end{array}$} & \multirow{2}{*}{$\begin{array}{c}\begin{array}{c}\text { Amounts of Starter Fertilizers } \\
\left(\mathrm{L} \mathrm{ha}^{-1}\right)\end{array} \\
\text { Starter-A }\end{array}$} & \multicolumn{3}{|c|}{$\begin{array}{l}\text { Amounts of Mineral Fertilizers } \\
\text {-Sub Treatments }\left(\mathrm{kg} \mathrm{ha}^{-1}\right)\end{array}$} \\
\hline & & $\begin{array}{c}\mathrm{T}_{0} \\
\text { NPK + KAN } \\
\left.\text { (Plots } \mathrm{E}_{1}-\mathrm{E}_{5}\right)\end{array}$ & $\begin{array}{c}\mathrm{T}_{1} \\
\mathrm{NPK}+\mathrm{KAN} \\
\left(\text { Plots } \mathrm{E}_{6}-\mathrm{E}_{10}\right)\end{array}$ & $\begin{array}{c}\mathrm{T}_{2} \\
\text { NPK + KAN } \\
\left(\text { Plots } \mathrm{E}_{11}-\mathrm{E}_{15}\right)\end{array}$ \\
\hline $\mathrm{TT}_{0}$-control & 0 & & & \\
\hline $\mathrm{TT}_{1}$-point form & 35 & & & \\
\hline $\mathrm{TT}_{2}$-belt form & 50 & $0+0$ & $150+100$ & $300+200$ \\
\hline $\mathrm{TT}_{3}-$ point form & 70 & & & \\
\hline $\mathrm{TT}_{4}$-belt form & 100 & & & \\
\hline
\end{tabular}

\subsection{Data Analysis}

A set of 90 observations of corn yield, collected and measured during this research was subjected to statistical data analysis. Mean values and standard deviations were calculated and visualized to obtain an insight into the overall trend. Differences between mean values of achieved yields obtained by applying different treatments were analyzed by two-factor analysis of variance and post-hoc Tukey honest significant difference (HSD) test, where the influence of mineral fertilizer treatment and the influence of liquid starter fertilizer treatment were observed as factors.

All calculations, tests and data visualization were carried out using $\mathrm{R}$ programming language, v4.0.0, with a significance level of $p=0.05$.

\section{Results}

Data on the amount of precipitation and mean monthly air temperatures for the observed sites are shown in Table 5 . The conditionally optimal values of precipitation and air temperature $[35,36]$ are presented along with the monthly values for the period 2016-2018.

Table 5. Mean monthly air temperatures, precipitation amounts at sites 1 and 2, conditionally optimal average temperature values and conditionally optimal precipitation amounts.

\begin{tabular}{|c|c|c|c|c|c|c|c|c|}
\hline Year & Locality & April & May & June & July & August & September & Unit \\
\hline \multirow{4}{*}{2016} & \multirow{2}{*}{1} & 60.5 & 138.3 & 125.9 & 79.1 & 124.7 & 55 & $\mathrm{~mm}$ \\
\hline & & 17 & 17.4 & 22.8 & 24.4 & 22.1 & 20 & ${ }^{\circ} \mathrm{C}$ \\
\hline & \multirow{2}{*}{2} & 57.9 & 63.4 & 156 & 34.7 & 50.6 & 60.1 & $\mathrm{~mm}$ \\
\hline & & 20.4 & 22.2 & 27.4 & 28.7 & 27.8 & 25.3 & ${ }^{\circ} \mathrm{C}$ \\
\hline \multirow{4}{*}{2017} & \multirow{2}{*}{1} & 81.2 & 77.3 & 47.4 & 26.5 & 46.1 & 63.1 & $\mathrm{~mm}$ \\
\hline & & 13.2 & 18.5 & 24.2 & 26.3 & 27.3 & 19.3 & ${ }^{\circ} \mathrm{C}$ \\
\hline & \multirow{2}{*}{2} & 45.6 & 82.1 & 35.8 & 37.7 & 26.6 & 58.2 & $\mathrm{~mm}$ \\
\hline & & 17.7 & 23.2 & 29.4 & 31.1 & 32.3 & 23.7 & ${ }^{\circ} \mathrm{C}$ \\
\hline \multirow{4}{*}{2018} & \multirow{2}{*}{1} & 50.5 & 88.7 & 198.5 & 216.1 & 6.6 & 17.7 & $\mathrm{~mm}$ \\
\hline & & 19.1 & 21.1 & 21.6 & 21.7 & 25.2 & 20.6 & ${ }^{\circ} \mathrm{C}$ \\
\hline & \multirow{2}{*}{2} & 39.7 & 42.6 & 78.7 & 89.9 & 30.8 & 15.2 & $\mathrm{~mm}$ \\
\hline & & 23.1 & 26.3 & 27.1 & 27.4 & 30.8 & 26.2 & ${ }^{\circ} \mathrm{C}$ \\
\hline \multicolumn{2}{|c|}{$\begin{array}{c}\text { Conditionally optimal } \\
\text { precipitation }\end{array}$} & 50 & 75 & 90 & 100 & 95 & 80 & $\mathrm{~mm}$ \\
\hline \multicolumn{2}{|c|}{$\begin{array}{l}\text { Conditionally optimal } \\
\text { temperature }\end{array}$} & 15 & 18.3 & 20 & 23.3 & 22.8 & 18 & ${ }^{\circ} \mathrm{C}$ \\
\hline
\end{tabular}

Based on the presented values, it can be stated that the amount of precipitation during July and August at both sites was less than conditionally optimal. Lack of water and average temperatures 
higher than conditionally optimal led to a decrease in yield during the research in relation to the genetic potential of the cultivated corn hybrid ZP 427.

Corn yield measured in this research ranged from $1.86 \mathrm{tha}^{-1}$ up to $6.50 \mathrm{tha}^{-1}$, having overall mean of $3.73 \mathrm{tha}^{-1}$. Mean values of yield observed in different years depending on the liquid fertilizer treatment are presented in Table 6.

Table 6. Mean corn yields from all three years of the research, depending on the liquid fertilizer treatment $\left(\mathrm{TT}_{0}-\mathrm{TT}_{4}\right)$.

\begin{tabular}{ccccccc}
\hline \multirow{2}{*}{ Year } & \multicolumn{6}{c}{ Treatment (t ha $\left.{ }^{-1}\right)$} \\
\cline { 2 - 7 } & $\mathbf{T T}_{\mathbf{0}}$ & $\mathbf{T T}_{\mathbf{1}}$ & $\mathbf{T T}_{\mathbf{2}}$ & $\mathbf{T T}_{\mathbf{3}}$ & $\mathbf{T T}_{\mathbf{4}}$ & Overall Mean \\
\hline 2016 & 3.73 & 4.14 & 4.17 & 4.42 & 4.51 & 4.19 \\
2017 & 2.75 & 2.95 & 2.89 & 3.21 & 3.21 & 3.00 \\
2018 & 3.70 & 3.89 & 3.99 & 4.29 & 4.12 & 4.00 \\
Overall mean & 3.39 & 3.66 & 3.68 & 3.97 & 3.95 & 3.73 \\
\hline
\end{tabular}

$p$-values from two factor analysis of variance for treatments $\mathrm{TT}_{0}-\mathrm{TT}_{4}$ and sub treatments $\mathrm{T}_{0}-\mathrm{T}_{1}$ are given in Table 7 . Statistically significant values are marked with $(* *)$ for significance level of 0.001 and $\left.{ }^{* *}\right)$ for significance level of 0.01 . There was no interaction between treatment and sub treatment.

Table 7. $p$-values from two factor analysis of variance for treatments $\mathrm{TT}_{0}-\mathrm{TT}_{4}$ and sub treatments $\mathrm{T}_{0}-\mathrm{T}_{1}$

\begin{tabular}{ccccc}
\hline & \multicolumn{4}{c}{$p$-Values } \\
\cline { 2 - 5 } & $\mathbf{d f}$ & $\mathbf{2 0 1 6}$ & $\mathbf{2 0 1 7}$ & $\mathbf{2 0 1 8}$ \\
\hline Sub treatment & 2 & $1.143 \times 10^{-11 * * *}$ & $1.644 \times 10^{-5 * * *}$ & $1.968 \times 10^{-8 * * *}$ \\
Treatment & 4 & $0.00575^{* *}$ & 0.4944 & 0.1437 \\
Sub treatment $\times$ Treatment & 8 & 0.94973 & 0.9998 & 0.9982 \\
\hline
\end{tabular}

Note: Statistically significant values are marked with $\left(^{* * *}\right)$ for significance level of 0.001 and $\left.{ }^{(* *}\right)$ for significance level of 0.01 .

\section{Discussion}

Distribution of the yield values is presented with boxplots in Figure 5 (yield for each year), Figure 6 (yield for each treatment with liquid fertilizer) and Figure 7 (yield depending on the treatment with liquid fertilizer by year), showing interquartile range (IQR), minimal, median and maximal values for each data subset presented.

Distribution of the values of the yields obtained by years (Figure 5) revealed lower values in 2017 for all variants of mineral and starter fertilizer application. The low values of the yields obtained were caused by the insufficient amount of precipitation, significantly less than the conditionally optimal ones, which was especially noticeable during July and August 2017 at both sites.

Figure 6 shows the obtained yield values depending on the amount of applied starter fertilizer. There was an increase in the value of yield with an increase in the amount of applied fertilizer $\mathrm{TT}_{1}-\mathrm{TT}_{2}-\mathrm{TT}_{3}-\mathrm{TT}_{4}$, regardless of the technique of application ('point' or 'belt') of this fertilizer. It was noticed that 'point' form application and smaller doses of starter fertilizer achieved approximate values of corn yield in relation to the 'belt' form application at higher doses. The difference in the amount of applied starter fertilizer between $\mathrm{TT}_{1}$ and $\mathrm{TT}_{2}$, as well as between $\mathrm{TT}_{3}$ and $\mathrm{TT}_{4}$, was without a statistically significant difference in the values of yields of the observed treatments.

Obtained values of yield depending on the liquid starter fertilizer treatment for the period 2016-2018 are shown in Figure 7. Grain yield per hectare varied statistically significantly depending on the applied fertilization system at both sites during the years of study. The lowest yield values were obtained in treatments where minimal amounts of mineral and starter fertilizers were applied. The sub 
treatment with mineral fertilizer $\left(\mathrm{T}_{0}, \mathrm{~T}_{1}, \mathrm{~T}_{2}\right)$ gave statistically significant differences in yields in all three years (with values of $p<0.001$ ). The highest values of achieved yields at both sites were obtained in the sub treatments with the largest amounts of applied mineral fertilizers $\mathrm{T}_{2}$ (Table 4). As for the mineral fertilization treatment, subsequent tests (Tukey HSD) showed the presence of a difference in all three sub treatments with $p$ values less than 0.001 . The treatment with starter fertilizer showed a statistically significant effect only in $2016(p=0.00575)$. Regarding the 2016 liquid fertilizer treatment, there was a statistically significant difference between $\mathrm{TT}_{3}$ treatment and $\mathrm{TT}_{0}$ control $(p=0.01)$, and $\mathrm{TT}_{4}$ and $\mathrm{TT}_{0}$ control $(p=0.005)$.

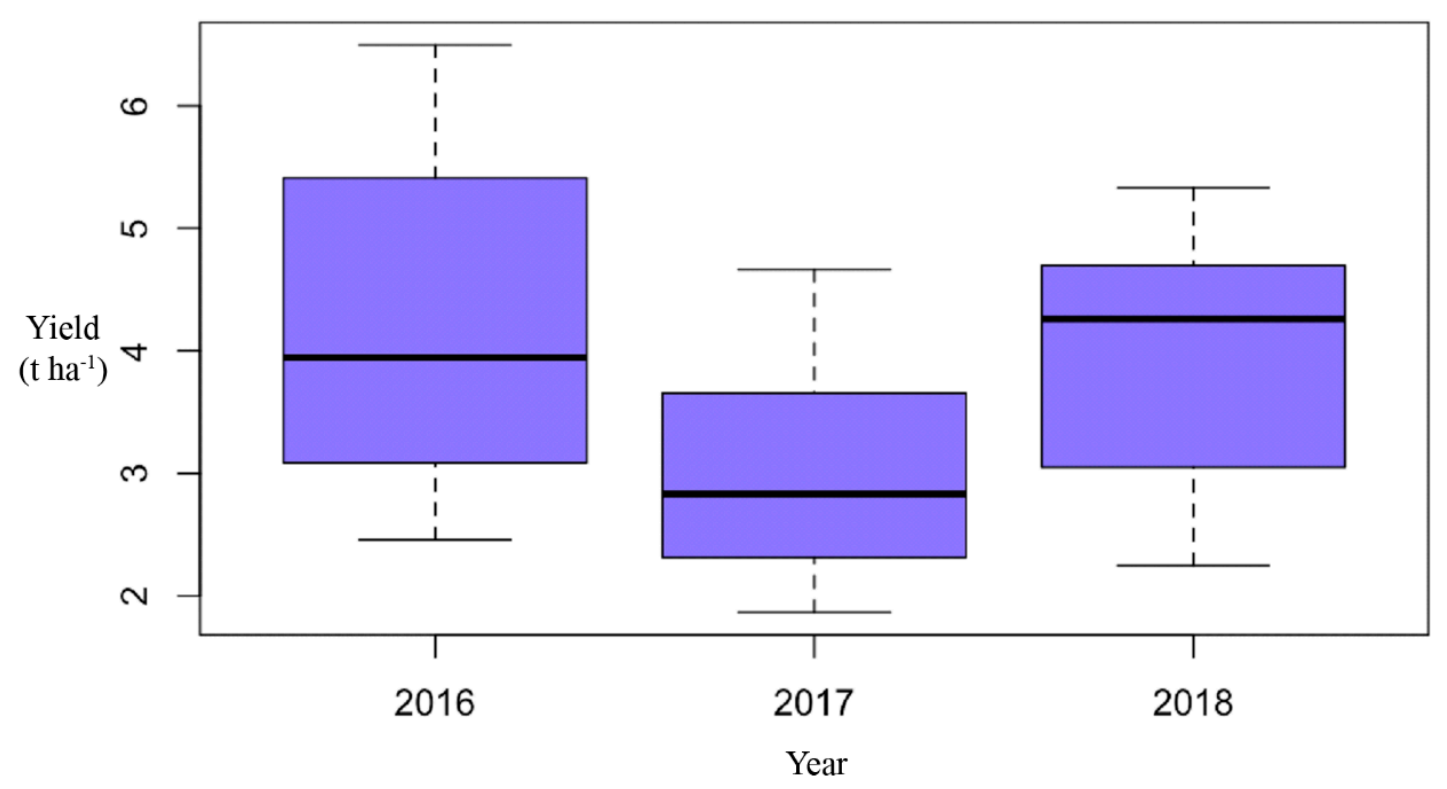

Figure 5. Yield values depending on the year.

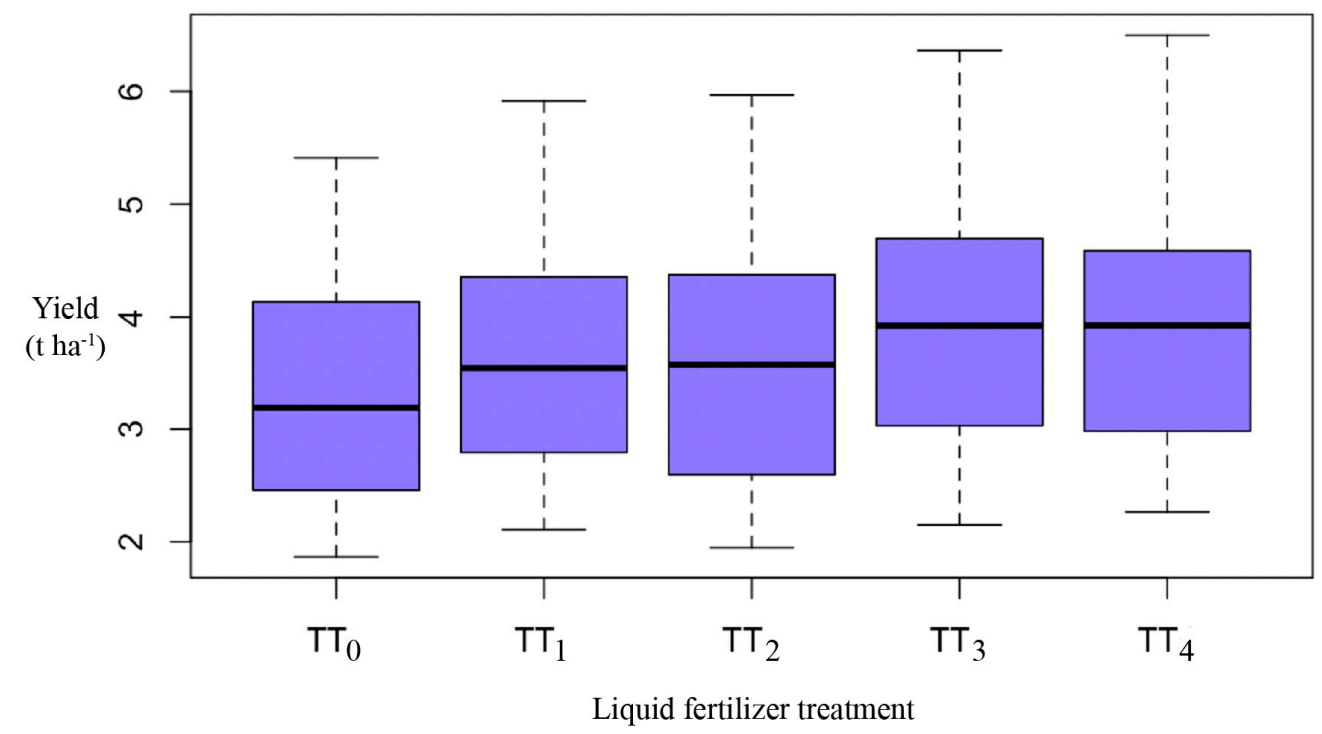

Figure 6. Yield values depending on the amount of applied starter fertilizer.

As expected, the highest overall mean values of yield were obtained in experiments where starter fertilizer was applied along with mineral fertilizer (NPK). These values were recorded in each year of the research on both experimental sites. The increase in corn yield (mean values), in comparison with control plot, was 7.9-17.1\%, depending on the applied liquid starter fertilizer treatments $\left(\mathrm{TT}_{1}, \mathrm{TT}_{2}, \mathrm{TT}_{3}\right.$ or $\mathrm{TT}_{4}$ ). Similar results were reported by [39-41,45-47]. It was noted that, during the all three years of 
research period, there is no significant differences between overall mean values of yield in treatments $\mathrm{TT}_{1}$ and $\mathrm{TT}_{2}$, i.e., $\mathrm{TT}_{3}$ and $\mathrm{TT}_{4}$. The highest difference in yield of $2.5 \%$ appeared in 2018 between the treatments $\mathrm{TT}_{1}$ and $\mathrm{TT}_{2}$. Respectively, the highest difference in yield of $4.1 \%$ appeared in 2018 between the treatments $\mathrm{TT}_{3}$ and $\mathrm{TT}_{4}$ (see Table 2). Experimental results showed that with the application of $30 \%$ less of starter fertilizer in the 'point' form, the achieved values of yield were approximately the same as the values as in the case of applying a larger amount in the 'belt' form.

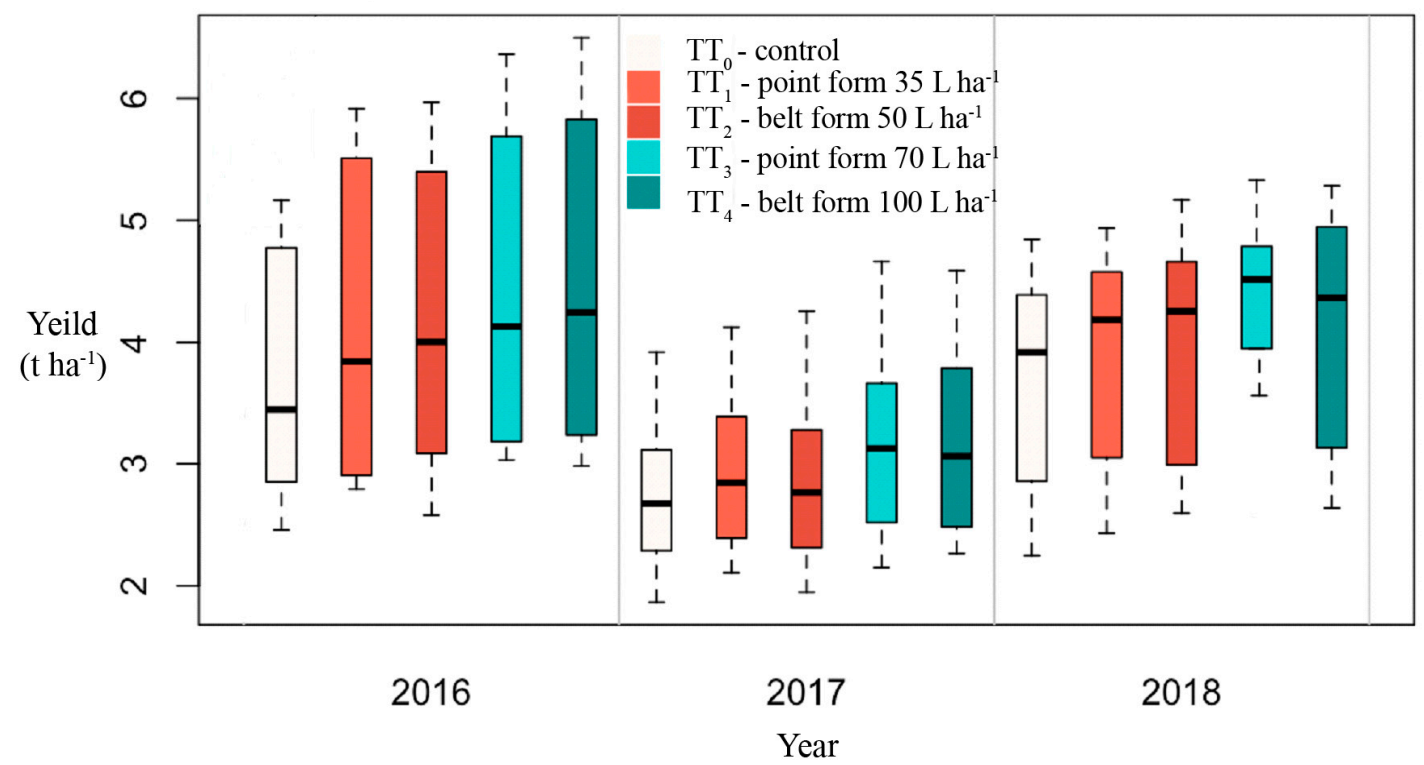

Figure 7. Yield values depending on the liquid starter fertilizer treatment.

\section{Conclusions}

The impact of application technique and rate of liquid starter fertilizer applied with a novel device on the production of corn was presented in this study. It shows that the yield results were obtained by applying mineral fertilizers $\left(\mathrm{T}_{0}, \mathrm{~T}_{1}\right.$ and $\left.\mathrm{T}_{2}\right)$ and different application techniques and amounts of starter fertilizer $\left(\mathrm{TT}_{0}, \mathrm{TT}_{1}, \mathrm{TT}_{2}, \mathrm{TT}_{3}\right.$ and $\left.\mathrm{TT}_{4}\right)$. Starter fertilizer was applied in the root system range of freshly germinated plants in the 'belt' and 'point' forms at different quantities $\left(35,50,70\right.$, and $\left.100 \mathrm{~L} \mathrm{ha}^{-1}\right)$, according to the two-by-two placement method, which led to intensive plant growth in the initial stages of development. The field trial was set up at two sites (two different land types), in the conditions of the natural water regime of the soil during the three vegetation seasons in the period 2016-2018. For this purpose, a prototype of the electronic device EUKU-01 was designed to provide a control of the seeding and fertilizing process. Data were statistically analyzed by two-factor analysis of variance, where the influence of mineral fertilizer treatment and the influence of liquid starter fertilizer treatment were observed as factors.

Corn yield measured in this research ranged from $1.86 \mathrm{tha}^{-1}$ up to $6.50 \mathrm{tha}^{-1}$, having an overall mean of $3.73 \mathrm{t} \mathrm{ha}^{-1}$. The lower values of the yields obtained were in 2017 and were caused by the insufficient amount of precipitation, significantly less than the conditionally optimal ones. The increase in the amount of applied mineral fertilizers, increased the value of yield. Grain yield per hectare varied statistically significantly depending on the applied fertilization system at both sites during all the years of study. The highest overall mean values of yield were obtained in experiments where starter fertilizer was applied along with mineral fertilizer. The increase in corn yield (mean values), in comparison with control plot, was $7.9-17.1 \%$, depending on the applied liquid starter fertilizer treatments. The highest difference in yield of $2.5 \%$ appeared in 2018 between the treatments $\mathrm{TT}_{1}$ and $\mathrm{TT}_{2}$, i.e., $4.1 \%$ in 2018 between the treatments $\mathrm{TT}_{3}$ and $\mathrm{TT}_{4}$. Results obtained showed that with the application of $30 \%$ less amount of starter fertilizer in the 'point' form, achieved values of yield were approximately the same as the values in the case of applying a larger amount in the 'belt' form. The application of liquid 
starter fertilizer in the technology of corn production affects the increase in yield. The difference in the achieved values of yield between the aforementioned treatments was not statistically significant in relation to liquid starter fertilizer savings that can be achieved by applying 'point' form. This way, the corn can be produced at lower total production costs.

Further research will be oriented toward the justification of the 'point' form starter fertilizer application on other soil types and other field crops.

Author Contributions: Conceptualization, M.D., K.G., M.P., I.Z., V.S.; methodology, M.D., K.G., M.P., I.Z., V.S.; validation, M.D., K.G., M.P., I.Z., V.S.; formal analysis, M.D., K.G., M.P., I.Z., V.S., P.S., G.S., and B.D.; investigation, M.D., K.G., M.P., I.Z., V.S., P.S., G.S., and B.D.; resources, M.D., K.G., M.P., I.Z., V.S., P.S., G.S., and B.D.; data curation, M.D., K.G., M.P., I.Z.; writing-original draft preparation, M.D., K.G., M.P., I.Z., V.S., and B.D.; writing-review and editing, M.D., K.G., M.P., I.Z., V.S., P.S., G.S., and B.D.; visualization, M.D., K.G., M.P., I.Z., V.S., P.S., G.S., and B.D.; supervision, K.G., M.P., V.S., and B.D.; project administration, B.D.; funding acquisition, V.S., G.S., and B.D.; All authors have read and agreed to the published version of the manuscript.

Funding: This research was funded by the Serbian Ministry of Education, Science and Technological Development for financing this research. The research was conducted as a part of the agreement on realization and financing of scientific research work in 2020 between the Ministry of Education, Science and Technological Development of the Republic of Serbia and University of Belgrade, The Faculty of Agriculture-contract number: 451-03-68/2020-14/200116.

Conflicts of Interest: The authors declare no conflict of interest.

\section{Nomenclature}

$\begin{array}{ll}\text { EUKU-01 } & \text { electronic device name } \\ \text { NPK } & \text { mineral fertilizer (Nitrogen, Phosphorous, Potassium) } \\ \text { KAN } & \text { mineral fertilizer (Potassium, Ammonia, Nitrogen) } \\ \mathrm{E} 1, \mathrm{E} 2, \ldots \mathrm{E} 15 & \text { experimental plots } \\ \mathrm{T}_{0}, \mathrm{~T}_{1} \text { and } \mathrm{T}_{2} & \text { mineral fertilizer sub treatments } \\ \mathrm{TT}_{0}, \mathrm{TT}_{1}, \ldots \mathrm{TT}_{4} & \text { starter fertilizer treatments } \\ \mathrm{Q} & \text { yield of dry corn grain, with } 14 \% \text { of water, } \mathrm{t} \mathrm{ha}^{-1} \\ \mathrm{P} & \text { yield of raw grain, } \mathrm{tha}{ }^{-1} \\ \mathrm{U} & \text { water content in the grain at the time of harvest, } \% \\ \mathrm{H} & \text { allowed water content in the grain }(14 \%), \%\end{array}$

\section{References}

1. Starcevic, L.J;; Latkovic, D. Favorable Year for Record Corn Yields. In 75 Years at the Service of Agriculture (1938-2013); Institute of Field and Vegetable Crops: Novi Sad, Serbia, 2006.

2. Egli, D.B. Comparison of Corn and Soybean Yields in the United States: Historical Trends and Future Prospects. Agron. J. 2008, 100, S79-S88. [CrossRef]

3. Assefa, Y.; Vara-Prasad, P.V.; Carter, P.; Hinds, M.; Bhalla, G.; Schon, R.; Jeschke, M.; Paszkiewicz, S.; Ciampitti, I.A. A New Insight into Corn Yield: Trends from 1987 through 2015. Crop Sci. 2017, 57, 2799-2811. [CrossRef]

4. Elmore, R.; Al-Kaisi, M.; Hanna, M. Corn Seeding Depth: Back to the Basics; University of Maryland Extension: College Park, MD, USA, 2014.

5. Kostic, M.; Rakic, D.; Radomirovic, D.; Savin, L.; Dedovic, N.; Crnojevic, V.; Ljubicic, N. Corn seeding process fault cause analysis based on a theoretical and experimental approach. Comp. Electron. Agric. 2018, 151, 207-218. [CrossRef]

6. Poncet, A.M.; Fulton, J.P.; McDonald, T.P.; Knappenberger, T.; Shaw, J.N.; Bridges, R.W. Effect of Heterogeneous Field Conditions on Corn Seeding Depth Accuracy and Uniformity. Appl. Eng. Agric. 2018, 34, 819-830. [CrossRef]

7. Stanacev, V.; Savic, S.; Kovcin, S.; Starcevic, L.j; Latkovska, M.; Latkovic, D. Influence of fertilization on grain chemical characteristics and yield of selected NS maize hybrids. Acta Periodica Tehnol. 2000, 31, 207-212.

8. Shapiro, C.A.; Ferguson, R.B.; Hergert, G.W.; Wortmann, C.S.; Walters, D.T. Fertilizer Suggestions for Corn; University of Nebraska Extension: Lincoln, NE, USA, 2008. Available online: https://agronomy.unl.edu/ faculty/ferguson/ec117.pdf (accessed on 4 July 2020). 
9. Latkovic, D.; Jacimovic, G.; Marinkovic, B.; Malesevic, M.; Crnobarac, J. Fertilization system as a function of maize yield in monoculture and two-field. Ann. Sci. Pap. 2009, 1, 77-84.

10. Spalevic, V.; Lakicevic, M.; Radanovic, D.; Billi, P.; Barovic, G.; Vujacic, D.; Sestras, P.; Khaledi Darvishan, A. Ecological-Economic (Eco-Eco) modelling in the river basins of Mountainous regions: Impact of land cover changes on sediment yield in the Velicka Rijeka in Montenegro. Not. Bot. Horti Agrobot. Cluj Napoca 2017, 45, 602-610. [CrossRef]

11. McDaniel, M.D.; Walters, D.T.; Bundy, L.G.; Li, X.; Drijber, R.A.; Sawyer, J.E.; Castellano, M.J.; Laboski, C.A.M.; Scharf, P.C.; Horwath, W.R. Combination of biological and chemical soil tests best predict maize nitrogen response. Agron. J. 2020, 112, 1263-1278. [CrossRef]

12. Teare, I.D.; Wright, D.L. Corn Hybrid-Starter Fertilizer Interaction for Yield and Lodging. Crop Sci. 1990, 30, 1298-1303. [CrossRef]

13. Mascagni, H.; Boquet, D. Starter Fertilizer and Planting Date Effects on Corn Rotated with Cotton. Agron. J. 1996, 88, 975-982. [CrossRef]

14. Mallarino, A.P.; Bergmann, N.; Kaiser, D.E. Corn Responses to In-Furrow Phosphorus and Potassium Starter Fertilizer Applications. Agron. J. 2011, 103, 685-694. [CrossRef]

15. Bundy, L.G.; Andraski, T.W. Site-Specific Factors Affecting Corn Response to Starter Fertilizer. J. Product. Agric. 2013, 12, 664-670. [CrossRef]

16. Penas, E.J.; Herget, G.W. Using Starter Fertilizers for Corn, Grani Sorghum and Soybeans; Cooperative Extension, Institute of Agriculture and Natural Resources; University of Nebraska: Lincoln, NE, USA, 1990.

17. Rehm, G.W.; Lamb, J.A. Corn Response to Fluid Fertilizers Placed Near the Seed at Planting. Soil Sci. Soc. Am. J. 2009, 73, 1427-1434. [CrossRef]

18. Steele, K.W.; McCormick, S.J.; Percival, N.; Brown, N.S. Nitrogen, phosphorus, potassium, magnesium, and sulphur requirements for maize grain production. N. Z. J. Exp. Agric. 1981, 9, 243-249. [CrossRef]

19. Hergert, G.W.; Wortmann, C.S.; Ferguson, R.B.; Shapiro, C.A.; Shaver, T.M. Using Starter Fertilizers for Corn, Grain Sorghum, and Soybeans; University of Nebraska Extension: Lincoln, NE, USA, 2012. Available online: http://extensionpublications.unl.edu/assets/pdf/g361.pdf (accessed on 4 July 2020).

20. Carsky, R.J.; Reid, W.S. Response of Corn to Zinc Fertilization. J. Prod. Agric. 1990, 3, 502-507. [CrossRef]

21. Mirta, R.; Bukvic, G.; Josipovic, M. Response of Corn to Zinc Fertilization. Energy Effic. Agric. Eng. 2002, 1, 131-136.

22. Hajabbasi, M.A.; Schumacher, T.E. Phosphours effects on root growth and development in two maize genotypes. Plant Soil 1994, 158, 39-46. [CrossRef]

23. Alley, M.; Reiter, S.; Thomason, W.; Reiter, M. Pop-Up and/or Starter Fertilizers for Corn; Virginia Cooperative Extension: Blacksburg, VA, USA, 2010; pp. 1438-3002.

24. Hedges, W. Starter Fertilizer Management for Corn and Soybean in the Southern Plains. Bachelor's Thesis, Oklahoma State University, Stillwater, OK, USA, 2014. Available online: https://hdl.handle.net/11244/9329 (accessed on 4 July 2020).

25. Beegle, D.; Roth, G.; Lingenfelter, D. Starter Fertilizer. In Penn State Extension, Agronomy Facts 51; The Pennsylvania State University: State College, PA, USA, 2007.

26. Gordon, W.B. Starter Fertilizer Application Method and Composition in Reduce-Tillage Corn Production. Better Crops 2009, 93, 10-11.

27. Nkebiwe, P.; Weinmann, M.; Bar-Tal, A.; Müller, T. Fertilizer placement to improve crop nutrient acquisition and yield: A review and meta-analysis. Field Crop Sci. 2016, 196, 389-401. [CrossRef]

28. Nouraein, M.; Skataric, G.; Spalevic, V.; Dudic, B.; Gregus, M. Short-Term Effects of Tillage Intensity and Fertilization on Sunflower Yield, Achene Quality, and Soil Physicochemical Properties under Semi-Arid Conditions. Appl. Sci. 2019, 9, 5482. [CrossRef]

29. Jokela, W.E. Applying Starter Fertilizer. Advanced Silage Corn Management. 2004. Available online: https://farmwest.com/node/949 (accessed on 4 July 2020.).

30. McGrath, J.M.; Binford, G. Corn Response to Starter Fertilizer with and without AVAIL. Crop Sci. 2012, 11, 1-8. [CrossRef]

31. Endres, G.; Franzen, D.; Kandel, H.; Ostlie, M.; Schatz, B. Corn Response to Phosphorus Starter Fertilizer in North Dakota; North Dakota State University Extention Service: Fargo, ND, USA, 2017.

32. Bremner, J.M. Nitrogen Total. In Methods of Soil Analysis Part 3: Chemical Methods; SSSA Book Series 5; Sparks, D.L., Ed.; Soil Science Society of America: Madison, WI, USA, 1996; pp. 1085-1122. 
33. Egner, H.; Riehm, H.; Domingo, W.R. Untersuchungen über die chemische Bodenanalyse als Grundlage für die Beurteilung des Nahrstoffzustandes der Boden, II: Chemische Extractionsmetoden zu Phosphorund Kaliumbestimmung. Kungliga Lantbrukshügskolans Annaler 1960, 26, 199-215.

34. Spalevic, V. Assessment of soil erosion processes by using the 'IntErO model': Case study of the Duboki Potok, Montenegro. J. Environ. Prot. Ecol. 2019, 20, 657-665.

35. Nikolic, G.; Spalevic, V.; Curovic, M.; Khaledi Darvishan, A.; Skataric, G.; Pajic, M.; Kavian, A.; Tanaskovik, V. Variability of Soil Erosion Intensity Due to Vegetation Cover Changes: Case Study of Orahovacka Rijeka, Montenegro. Not. Bot. Horti Agrobo. 2019, 47, 237-248. [CrossRef]

36. Todorovic, J.; Lazic, B.; Komljenovic, I.; Nenadic, N.; Djurovka, M.; Janjic, V. Crops and Vegetable Manual; University of Banja Luka: Banja Luka, Bosnia and Herzegovina, 2003.

37. Murányi, E. Effect of plant density and row spacing on maize (Zea mays L.) grain yield in different crop year. Columella J. Agric. Environ. Sci. 2015, 2, 57-63. [CrossRef]

38. Dražić, S.M. Development and Optimization of Novel Electronic Device for Automatic Control of Liquid Starter Fertilizer Injection in Maize Sowing; Faculty of Agriculture, University of Belgrade: Belgrade, Serbia, 2017.

39. Camberato, J.; Hornaday, C.; Nielsen, B. Response of Corn to Starter Fertilizer-2015 Research Update; Agronomy Department, Purdue University: West Lafayette, IN, USA, 2016.

40. Ritchie, K.B.; Hoeft, R.G.; Nafziger, E.D.; Gonzini, L.C.; Warren, J.J.; Banwart, W.L. Starter Fertilizers for No-till Corn. Better Crop. 1996, 80, 6-9.

41. Quinn, J.D.; Lee, D.C.; Poffenberger, J.H. Corn Yield Response to Sub-surface Banded Starter Fertilizer in the U.S.: A Meta-analysis. Field Crop Res. 2020, 254. [CrossRef]

42. Liang, B.C.; MacKenzie, A.F.; Schnitzer, M.; Monreal, C.M.; Voroney, P.R.; Beyaert, R.P. Management-induced change in labile soil organic matter under continuous cornin eastern Canadian soils. Biol. Fertility Soil. 1997, 26, 88-94. [CrossRef]

43. Glamoclija, D.J. Special Farming —Cereals and Legumes; Faculty of Agriculture, University of Belgrade: Belgrade, Serbia, 2012.

44. Gatiboni, L.; Osmond, D.; Hardy, D.; Kulesza, S. Starter Phosphorus Fertilizer and Additives in North Carolina Soils: Use, Placement, and Plant Response. Available online: https://content.ces.ncsu.edu/starter-phosphorusfertilizer-and-additives-in-nc-soils-use-placement-and-plant-response (accessed on 4 July 2020).

45. Touchton, J.T.; Karim, F. Corn Growth and Yield responses to Starter Fertilizers in Conservation-Tillage Systems. Soil Tillage Res. 1986, 7, 135-144. [CrossRef]

46. Dražić, M.; Pajić, M.; Dumanović, Z.; Radojičić, D.; Gligorević, K.; Stojanović, M.; Božić, S. Effects of mechanized method of liquid fertilizer application in corn production. Poljoprivredna Tehnika 2012, 37, 63-70.

47. Oljača, M.; Raičević, D.; Ercegović, Đ; Vukić, Đ; Oljača, S.; Radojević, R.; Zivković, M.; Gligorević, K.; Pajić, M.; Spalevic, V.; et al. Aspects of using machinery and tools in contemporary plant production-Marsh soils case. Agric. For. 2014, 60, 39-51.

(C) 2020 by the authors. Licensee MDPI, Basel, Switzerland. This article is an open access article distributed under the terms and conditions of the Creative Commons Attribution (CC BY) license (http://creativecommons.org/licenses/by/4.0/). 